\title{
Some Criminogenic Factors of Trafficking in Human Beings; Cases of Judicial Practice in Albania
}

\author{
Ma. Naim Tota \\ District Prosecution of Tirana, Albania \\ Email: naimtota@yahoo.com
}

Doi:10.5901/ajis.2014.v3n4p361

\section{Abstract}

This research has been conducted to examine the criminal etiology which is focused in studying and analyzing the risk factors that are highly associated with the criminal conduct. These factors are related to the knowing of the resources and defining the circumstances of criminality such as human being's trafficking. Thus, criminal etiology has been considered until lately as the main part of the science of criminology. It is also considered as an important section of studies and researches onto human's trafficking criminality. This research scope is to show the causes and the circumstances that are being considered of all criminal behaviors and other sociological factors (objective and subjective factors which are involved in recognizing, defining and analyzing the criminality's factors, causes and resources within a country, which in our case it is Albania). Along with trafficking for recruiting persons in a criminal network, for illicit organ transplant, or even for different exploitations, trafficking for sexual exploitation remains the widest category that compounds this crime. The simplest reason is that this kind of "service" will always generate the biggest incomes for the traffic dealers. This research has put into evidence the major factors which contribute to the trafficking of human beings mainly in Albania during the period from 2001 to 2005.

Keywords: trafficking in human being, traffic dealers, victim, felonious factors, criminal personality, socio-economic motives, and discrimination.

\section{Introduction}

Trafficking in human beings is a serious crime which consists in abusing with the human rights, such as the rights to a life, health, freedom, dignity, sexual integrity etc. Trafficking also consists of individuals which are vulnerable to exploitation by criminals for the sole purpose that is the financial profits.

Being trafficked means physical and psychological abuse of the victims from the moment of recruitment when individuals are forced, lured, abducted or fallen into the hands of traffickers in different ways. The trafficking victims may remain affected by the caused trauma for a long time, even after the trafficking conditions of exploitation have been overcame.

In 2004, in the Southeastern Europe, there have been identified and assisted 6,255 victims of human trafficking. Another concerning fact is the considerable number of the child victims, which constitutes a percentage which is rising continuously. (Surtees, 2005).

It emerged in Albania as a new phenomenon after the ' 90 and ever since human trafficking recognized a wide spread. Considering the fact that this situation was favored, especially at the beginning, by the inability of state institutions to fight it effectively, the lack of duly legal provisions and because of sociological and political chaos at the time (in ' 90 Albania made a big change from a strong communist regime and censured economy to democracy and capitalism). From the fall of the communist regime, Albania has experienced social, political and economic transition, when among others recognized is the phenomenon of trafficking in human beings.

Albania's geographical position as a cross link to eastern countries, has transformed it into a transit country to western ones. In this respect, Albania is being considered not only a country of origin, but also a transit country for trafficked persons, particularly from eastern countries and from the countries so-called "third world"

In order to stop this modern form of human slavery, the international community and organizations in different levels, have adopted a series of measures with the intention to prevent trafficking, protect the victims and to bring traffickers against justice.

The Constitution of the Republic of Albania considers human dignity as one of the basic human rights and freedom and provides the legal obligation of public authorities to take all necessary measures to guarantee it. 
It is highly important to stress that the crime of trafficking in human beings works out only because there is a wealth supply with victims, which are eager to see migration as a way out to improve living conditions in their country of origin. This desire towards migration is fostered by a complex combination of social and economic factors.

\section{Push and Pull Factors of Human Trafficking}

Behind the trafficking in human beings who is considered as a "fast-growing epidemic" not only in Albania but all over the world, there can be a variety of considered elements, such as:

- Within the countries of origin, there are always victims which constitute the basis for the exploitation process.

- Within the countries of destination, sex markets that constantly increase the demand for "special services" of the victims.

- Organized criminal networks have taken control over the economic situation of "supply and demand" and use to traffic and exploit victims in order to recover the extraordinary personal economic benefits. (UNHCR, 2000 \& Bodin 2001)

While the criminal phenomenon of trafficking in human beings is based on a simple economic equation of "supply and demand", the real causes and characteristics of this crime are much more complex.

\subsection{Push factors}

- Poverty;

- Lack of opportunities to improve life conditions;

- High unemployment;

- The labor market not opened to women and gender discrimination;

- Ethnic or sexual discrimination;

- Physical and/or psychological violence;

- Escape from prosecution;

- Escape from the violation of other human rights;

- The collapse of social infrastructure.

Another effective factor of human trafficking in Albania, despite those mentioned above, is the decline of moral values and pride. The conducted polls, have shown that nowadays, Albanians prefer an adventurous life much more than a normal one. Albanian writer Ismail Kadare, in his book "Barbaric times" ("Kohë Barbare"), states that the decline of moral values is a characteristic of almost all the Eastern Europe countries in which there is appeared a kind of "vulgar materialism". (Kadare, 2000)

In relation to this ocurrence, it is also noticed the decline of the Albanian traditional pride. French scholar Zhak Burkari, have stated that "Albanians (villagers, mountaineers or soldiers) which i used to live and eat with, and staied in their homes, seemed to be greater sirs, compared to their Balcanic neighbors..." (Burkari, 2004)

The arised question is "Why are Albanians nowadays so "ready: to be involved in traffickings, considering that Albania is not poorer that it has been before?". It seems that there are reasons, perhaps more than poverty, which are related with the "lack of pride" such as the decline of selfconfidence, lack of a collective purpose, lack of a mutual (national) dream in which all could believe in. (Sokoli \& Gëdeshi, 2006)

\subsection{Pull factors:}

- To improve the standard of living and quality of life;

- Better access to a decent education;

- Lower discrimination or abuse;

- Application of minimum standards and individual rights;

- Bigger possibilities for better jobs;

- Demand for labor with satisfactory income and best work conditions;

- The market demand for sexual "services";

- The market demand for "workers in the sex industry" and high profits in return;

Push and pull factors cited above, are also present in all final decisions of the Serious Crimes Court of the 
Republic of Albania in the period from 2003 to 2012. Some of these decisions will be mentioned below in the analyses of objective and subjective factors of trafficking in human beings.

\section{Factors of Trafficking in Human Beings during the Period from 2003 To 2012}

\subsection{Objective factors of human trafficking.}

Early ' 90 s entered in the history of Albania as the period of overthrow of the previous social, economic and political system. The transition from communism to democracy in Albania was experienced as the "time of salvation". Building a "new life" which was expected to be completely different from that lived by then, therefore it was turned into a purpose that had to be reached by all means. Being tired from the previous regime and stressed by shock and collapse of the system, Albanian people were unprepared to deal with changes, uncertainties and social problems. Along with others, trafficking in human beings was one of these new phenomena. External criminogenic factors in particular have the greatest impact on commission of the criminal offenses of trafficking in human beings. (Halili, 2002, pg. 231) The external factors that are on favor to this criminal business as already mentioned are poverty, desperation, socio-economic crises, unemployment, disruption of family, violence, lack of education, gender discrimination, poor housing conditions, lack of information, and migration.

Based on court decisions for the offenses of trafficking in human beings for the period of time from 2003 to 2012, it results that socio-economic factors play the main role as criminogenic factors and then follow ideo-political factors whereas the micro-grouping factors are the last. Still, socio- pathological factors are not fare behind referring to their influence on this kind of crime.

Due to the observation of the final court decisions, it appears that for the offenses of human trafficking, the main factor is poverty as result of unemployment. This seems obvious if we refer to the decision of the District Criminal Court of Tirana July 2003, no. 587, which has sentenced E.A. According to this decision, E.A. who was an immigrant in Albania, notified two Tunisian nationals who entered without proper documents through the territory of Kosovo to Albania, intending Italy as their final destination. Persons trafficked (Tunisians) by the convicted E.A., were recruited because of poverty and the fact that they were unemployed, thus they intended to go in Italy for a better life.

These situations show that different countries are characterized by wide range of contradicts. On one hand, there are transformations and achievements in countries with high standards, and on the other hand there are very poor countries and regions, where the populations have no possibility to secure the basic needs for food, clothing and a house. (Halili, 2002, pg. 237)

Another factor that indicates the spread of this crime is family, which is also considered a criminogenic factor. In rural areas, the tradition of marriage in a very young age (often under the legal age of 16 years old) is still widely practiced. Moreover, especially in northern Albania, an unmarried girl living in her parents' house is a possible source of shame and displeasure in case when she loses her virginity outside marriage and dishonors the family name. In these communities an unmarried girl over the age of 20, may already be a victim of "malicious rumors". Therefore, once a girl reaches her sexual maturity, parents seek immediately to find a suitable husband.

Families in rural areas, which in general have more children, face serious economic difficulties. A request for marriage and a better life abroad is a potential opportunity for these families to improve its economic situation. Men immigrant in their thirties come from abroad and seek for 16 years old girls to get married. They do not prefer older women. If the girl is over 19 years old, she has minimal chances to get married. (Renton, 2001, pg. 22) An interviewed woman from a Berat's village confesses "There is nothing to do, no work at all. I spend most of the day at home. Even a dog has a better life than a woman". (Renton, 2001, pg. 22)

Moreover, the idea that individuals under 18 have rights, does not take place in rural areas. It is normal for children (particularly in very poor families) to start work from the age of 14.

First Instance of Serious Crimes Court in Tirana, on the dispositive part of the Decision No. 34, dated 29.10.2010 states that: "..... It results fully proved that the defendant Z.B. by taking advantage of the vulnerable position of the victim E.B. which was in a very difficult economic situation, acting through fraud (promise of marriage and attendance for a better life) has transferred E.B. from Albania to Macedonia, from Macedonia to Greece and with final destination France. Once arrived in France, the defendant has forced the victim E.B. to start working as a street prostitute, and as the victim refused to do this kind of "job", the defendant mistreated and threatened her with a knife.

Besides the aforementioned factors, for the crime of trafficking in women, there can be listed some other factors that influence and favor the growth of this crime. Continuous subjugation of women is present in many societies, 
especially reflected in the inequality between men and women in the economic, educational and employment opportunities. Many societies (including parts of Albanian society) still favor boys, and treat girls as aggravating factors in their family economies. Moreover, in countries with extreme poverty conditions, there are desperate families which use to sell girls to traffickers or brothels, in order to gain some money and at the same time to avoid expenses needed for their wedding.

Referred to Albania, the subjugation of women and inequality with men has its origin in "Kanun" (customary law), which treats women as a commodity or object, property of the husband. According to "Kanun" women can be sold, bought, violated and even murdered.

Worldwide demand for trafficked women and children for sexual exploitation, illicit works etc., is highly considered. The fulfillment of this "market demand" is accompanied by the satisfaction of winning multiple, persistent and non-taxable incomes, from the same victims and without much efforts. This satisfaction adds the "appetite" of traffickers to continue "working".

Legal gaps and lack of law implementation in many countries of origin, transit and destination, undermines efforts to fight human trafficking. On the other hand, prostitution is legally regulated in some countries, "tolerated" in some others and is widespread in many others. When the state authorities of the respective countries impose stringent legal measures, those measures are usually against prostitutes and rarely affect the trafficking dealers. Sanctions for human trafficking with purposes of sexual exploitation are relatively lower compared to those provided for other criminal activities related to trafficking such as drug or weapons trafficking.

The big purpose of illegal immigration inhibition in many countries (including even the United States), has led to the treatment of cases of trafficking as illegal immigration problem and consequently in treating victims as criminals. When police checks brothels, women often are punished, convicted, deprived from human rights in prisons and are immediately expelled from the country of destination. Very few steps are taken for providing them support, health care and the right to protection of life. Terrorized by fear of punishment over them and their families, victims rarely provide information for tutors and traffickers to the police. Thus, the number of denunciations also remains small because most governments do not provide adequate protection for witnesses and/or victims. The few countries that prosecute traffickers often treat victims as "worthless witness" and expel them just when they consider their presence as unnecessary.

Lack of interest, and in some cases cooperation in crime of some governments, is another huge problem. Many structures of law and government ignore victims of trafficking and hide the true purpose of the trafficking phenomenon. In some cases, police and other state authorities, accept bribes and help traffickers by selling them false identification documents. In addition, police of low ranges often are frightened from the retaliation by the criminals, and therefore prefer to deny or hide data on trafficking.

The geographical position of a country can be very favorable to human trafficking. Due to its geographical position, Albania is considered a country of origin, transit and also destination. Many Albanian girls are trafficked to Greece, Italy and other countries. At the same time, Albania serves as a transit country for Moldovan and Bulgarian women and girls to the destination countries such as Italy or other countries of Eastern Europe, while some of them are held to work as prostitutes in Albania.

Domestic violence is another factor that stimulates human trafficking. Living in a violent family, within which every right is denied, has driven many girls and women to leave at the first presented opportunity for them to do so. But, on the other hand very violent husbands or fathers have not hesitated to force their daughters and wives into prostitution to make a living. Likewise, most of trafficked children come from families with big social problems. Most of abused children are neglected or orphans, thus constituting an easy recruited contingent and easily usable by traffickers. Decision no. 3, dated 10.01.2011 of the Serious Crimes Court of Albania, inter alia argues: "...The departure to another city of the daughter from home with the defendant H.S. and without notifying her parents, created a difficult situation for her. After turning back home, for the victim there have been contradictions with her brothers E.V. and F.V. and her father, the witness H.V. These circumstances severely hampered the position of the victim in her family, and being in such difficult situation, the victim accepted to go abroad with the defendant, once she found support from him."

Lack of information creates opportunities to easily recruit victims. Being uninformed about what can be hidden behind a "guaranteed job", "marriage" or "happy life", a big number of victims have accepted immediately to go after people who have promised these "miracles". Likewise, the lack of information on human rights in the country of destination or information on institutions that can offer help if they need it, hinders their secession from the trafficking network.

Sometimes trafficking is seen as the only solution to economic, social or family problems. There are women and girls who, bounded by certain conditions "choose" to being trafficked and to work as prostitutes. This is considered as a 
unique opportunity to provide income for survival. Except this category, it should be noted another category where are included women that prefer to exercise this kind of profession, because it guarantees very good profits and thus creates the desired life.

\subsection{Subjective factors of human trafficking.}

After the above treatment of external or objective factors of human trafficking, it is important to stress that crime phenomenon of human trafficking and its causes cannot be duly and fully explained without the analysis of the internal or subjective factors, which have to do with the personality of the author of the crime. (Halili, 2002, pg. 321) When it comes to subjective factors, it is usually referred to the individual human personality, which in our case it is the traffickers' personality. In this respect, it is particularly emphasized the role and importance of the trafficker's bio-physique life and its links with criminal behavior and actions. Despite the development and mode of operation of the internal factors, it turns out that these factors have an impact on criminal behavior of traffickers.

The two important components for the development of a normal human personality are the psychological and biological basis. The psychological basis has impact and is reflected in the trafficker's behavior and actions, and this happens because the spiritual and psychological world of the human is very complex. Some actions and behaviors of crime authors cannot be easily understood, so they cannot be highlighted without a prior and proper analyze to his personality and psychic structure.

\subsubsection{Character traffickers and criminal behavior.}

At first instant personal character is considered as one of the main features of his personality. (Halili, 2002, pg. 322) In psychological and criminological literature, elements of the character are considered: free will, stability, determination, consistency, initiative, courage, loyalty, selflessness, self confidence etc. By the observation of the Albanian Court for Serious Crimes' decisions, we find that these values or features of character are not met by persons who have committed human trafficking and their attitudes are specifically negative towards certain moral values and society rules. This negative attitude is expressed by the flagrant violation of human rights provided in the Constitution of the Republic of Albania (Constitution of the Republic of Albania, 1998, art. 15,16,17,18,19,20) and the International Covenants on Human Rights; by denying acts and omissions committed intentionally; by not repenting for the offense committed; by keeping aggressive and indifferent attitudes of trafficked victims; by manipulating certain criminal episodes etc.

Convicted traffickers generally have week character and this is clearly settled in court decisions. They are shown as untruthful persons and subject to lower interest motives of greed. Regarding this evidence, the First Instance of the Serious Crimes Court of Albania, in the reasoning part of the Decision No. 3, dated 18.01.2005 states that the adult female victim A.F., on 07.04.2003 raised criminal charges against defendants H.A. and A.C. Both of them in cooperation with each other used to commit trafficking for the purpose of exploitation for prostitution to Italy the victim A.F. Due to fact that the defendant and the victim's family have been into a closed friendship, the defendant used this fact to trafficking their daughter by lies and promises for a better life abroad. The defendant and the victim travelled by speedboat to Brescia, Italy and after being accommodated in a house for some days, the defendant asks the victim to work as a prostitute. The victim claimed that the defendant recruited her through fraud in order to force her to work as a prostitute. During the stay at his disposal, the victim said that she had heard a phone conversation between the defendants. In this conversation, the defendant H.A. expressed to A.C. that he was not satisfied by the "recruited woman". After the continuous refusals from the victim to work as a prostitute and because of the defendants knew that she had brothers who were looking for her, in order not to fall into enmity, they decided to return home the victim in January 2002. Once she came in Albania, she pressed criminal charges against the traffickers. It is worth to note that by final verdict, the trial court sentenced the defendants for the offense of "Trafficking in women for prostitution", provided by the article114/b-2 of the Criminal Code of Albania with 17 years of imprisonment.

Referring to the temperament of sentenced persons, it is hard to discover which type of temperament they belong to, because the court decisions do not provide any information on this. Lack of information by courts decisions in this regard, has affected the execution institutions and specifically sociologists, psychologists, etc. on their rehabilitation into society integration. (Gashi, 2001, pg. 244) Based also on family situation and insufficient education, it can be said for sure that these are two other aspects that reflect in the criminal behavior of offenders, and this is pointed out quite easily in court decisions. 


\subsubsection{Social motives}

Social motives are considered all the incentives which are not born with the human and which do not have anatomicbiological character, but they are obtained during the process of development, education and improvement of the individual in society. (Halili, 2002, pg. 336) The number of social motives is very large and some of them are universal. The most important social motive regarding these phenomena is considered the motive for companionship, affirmation, the profit motive, fear, aggression etc.

The analysis of social factors is made in the elaboration of objective factors. The analysis of the material interest motive, since this kind of motive is present in all decisions of the Court for Serious Crimes of Albania. So, decision No.3 dated 28.04.2004, stated in its reasoning part that "The defendant D.I. .... through the promise of reward, in the last months of 1997, has obtained the consent of the parents of minors Sh.Z. and A.Z. to use them as beggars in Greece. The defendant took the two minors illegally to Thessaloniki, Greece. Upon arrival, he began to implement its criminal purpose, which was to extract profits through exploitation of minors Sh.Z. and A.Z. On Sundays, the children were being placed near the church of Thessaloniki. The minor victims were forced to achieve a certain amount of money, and if not, they were subjected to violence and mistreatment. To push the victims to beg for more and to justify violence against them, the defendant used to bring out on the street even his son. The victims used to work (not only begging, but also selling cigarettes, washing carpets etc.) all day from morning till evening and gave all the gained money to the defendant. The fact that the defendant took the victims with parent's consent, has not been valued by the court as a mitigating circumstance, because the victims were minors and their families have been in severe economic conditions which are intentionally used by the defendant to achieve his criminal purpose. It is important to mention that after some time, despite the request of the parents to return the children home, the defendant managed to keep and use the minors for his purposes.

Child trafficking in Greece for begging and for forced labor is alarming. It is estimated that only in Thessaloniki there are 1,000 children victims (mainly Albanian Roma children). (Renton, 2001, pg. 10) Trafficking in women, children, illegal immigrants, drugs and weapons constitute a multi-million dollar industry which employs directly and not directly many people in Albania. But, despite the fact that trafficking is now at the top of the policy agenda, yet, there are very few criminal prosecutions. As abovementioned, Albania has been a major transit country for trafficking. Each year, thousands of foreign women from countries such as Moldova, Romania and Ukraine. As a former employee of Interpol says "As long as the difficult economic conditions will prevail and the financial rewards for this kind of work will be so high, Albania will remain a source of child trafficking." (Renton, 2001, pg. 25)

Trafficked persons (victims) are people of different ages, among which, children and young individuals are preferred. Women and minor girls are the most vulnerable group and the most risky to be vulnerable to trafficking in this modern form of slavery. The victims are from different geographical areas and live in poor social and economic conditions. They are usually lured by false promises of jobs and better life for them and their families, but unfortunately they are forced to work in almost inhuman conditions, violated and sexually and physically abused. Since they are surrounded and unable to free themselves, they are forced to labor, used for prostitution, pedophilia, pornography, organ transplant, etc., and are intended to be sold and purchased, whenever their "owners" want to.

\section{Findings and Conclusions}

The positive steps taken by the Government of Albania, referred to the fight against organized crime, have prevented and combated organized crime in general and human trafficking specifically in Albania, indicating that the current level of response against this crime has never been higher before. Also, the awareness levels of law enforcement authorities (including the courts) is increased, victim protection and support is prioritized, and national action plans provide clear purposes of the strategy in the fight against human trafficking.

The investigation of labor exploitation is already an important issue provided in the agenda of the Albanian Government and many NGOs, demonstrating in this way the recognition and combating new forms of trafficking. Also, changing and drafting new criminal laws (procedural and material criminal law) has effectively responded to the phenomenon of trafficking, and at the same time the adaptation with European laws must go further, especially referred to the implementation process. 


\section{Theoretical Resources Used}

Contribution to the research on human trafficking phenomenon (mainly women and children), to the submission of the conditions, causes and motives behind this phenomenon, has given the used literature. Here are included scientific resources by Albanian and International authors. Reports from the organizations, such as the Albanian Helsinki Committee, UNICEF, and also court decisions mainly those from the Serious Crimes Court of Albania. Through this literature, this research provides not only a theoretical treatment and submission of the trafficking in human beings, but also real data regarding this crime are provided.

\section{Research Methodology}

From a technical perspective, the used methods in this research are the studies of individual cases and methods of court decision observation, mainly the decisions of the Serious Crimes Court and District Court of the Republic of Albania. This method is applied over a certain period of time, from 2003 to 2012. There are also used traditional and legal methods. Through these methods and research techniques, it is achieved to recognize and address certain aspects of the human trafficking crimes.

\section{Conclusions and Recommendations}

The positive steps taken by the Government of Albania, referred to the fight against organized crime, have prevented and fought human trafficking in Albania, indicating this way that the current level of response in the treatment of this crime has never been higher before.

The awareness levels of law enforcement authorities (including courts) have increased; victim protection and support is prioritized and national action plans provide the clear purposes of the strategy in the fight against human trafficking.

Investigation of labor exploitation is already a top issue in the agenda of the Albanian Government and the agendas of many NGOs, thus demonstrating the necessity of recognition, adaptation and fighting new forms of trafficking.

Also, amendments or drafting new criminal law (procedural and material law) in order to effectively respond to the phenomenon of trafficking, and at the same time the adaptation with European laws must go further, especially as it regards to the law implementation.

\section{References}

Bodin, C. B., (2001). Faktorët social-ekonomik faktor të përfshirjes së grave moldave në prostitucion, trafikim dhe skllavërimin e seksit. Burkari, Zh. (2004). Shqipëria dhe Shqipëtarët. Tiranë: Dituria.

Federata e Helsinkit për të Drejtat e Njeriut. (2000). Women 2000, një investigim në statusin e të drejtave të grave në Europën Qendrore dhe Jugore dhe në Shtetet e Reja të Pavarura.

Gashi, R. (2001). Ekzekutimi i Dënimit me Burgim në Shqipëri. Prishtinë: Art House.

Global Survival Network. (1997). Krimi \& Skllavërimi: Një ekspoze e trafikut të grave për prostitucion nga Shtetet e Reja të Pavarura.

Gjykata e Apelit për Krimet e Rënda të Republikës së Shqipërisë. (2004 - 2012). Vendimet.

Gjykata e Krimeve të Rënda të Republikës së Shqipërisë. (Tetor 2004). Vendim nr. 29.

Gjykata e Krimeve të Rënda të Republikës së Shqipërisë. (28.04.2004). Vendim nr. 3.

Gjykata e Krimeve të Rënda të Republikës së Shqipërisë. (23.03.2005). Vendim nr. 18. dhe nr. 39 akti.

Gjykata e Krimeve të Rënda të Republikës së Shqipërisë. (18.01.2005). Vendim nr. 3 dhe nr. 4/22 akti.

Gjykata e Krimeve të Rënda të Republikës së Shqipërisë. (29.10.2010).Vendimin nr. 34.

Gjykata e Krimeve të Rënda të Republikës së Shqipërisë. (10.01.2011). Vendimi nr. 3

Gjykata e Rrethit Tiranë të Republikës së Shqipërisë. (Qershor 2003). Vendim nr. 588.

Gjykata e Rrethit Tiranë të Republikës së Shqipërisë. (Qershor 2003). Vendim penal nr. 587.

Halili, R. (2002). Kriminologjia. Botim i tretë. Prishtinë: Multigraphic.

Kadare, I. (2000). Moda antishqiptare dhe ndërgjegjja europiane. Revista Politika \& Shoqëria. Vëll 3, Nr.2(7). Tirane.

Kuvendi i Shqipërisë. (1998). Kushtetuta e Republikës së Shqipërisë. Tiranë: Qendra e Publikimeve Zyrtare.

Kuvendi i Shqipërisë. (2010). Kodi Penal i Republikës së Shqipërisë. Tiranë: Qendra e Publikimeve Zyrtare.

Renton, D. (2001). Trafikimi i Fëmijëve në Shqipëri.

Sokoli, L. \& Gëdeshi, I. (2006). Trafikimi: Rasti i Shqipërisë. Tiranë: Rinia

Surtees, R. (2005). Raporti i Dytë Vjetor për Viktimat e Trafikimit në Europën Juglindore. Regional Clearing Point. Gjeneva: IOM

UNICEF. (2000). Trafikimi i qenieve njerëzore në Europën Jug-Lindore, një investigim i situatës aktuale dhe të reagimeve ndaj trafikimit të qenieve njerëzore në Shqipëri, Bosnjë dhe Herzegovinë, Kroaci, në Republikën Federale të Jugosllavisë dhe në ishRepublikën Jugosllave të Maqedonisë. 
